\title{
THE HISTORICAL SITE UMPAK RESHOGATI IN SOGATEN (A STUDY OF CULTURAL VALUES AND THEIR POTENTIALS FOR RESOURCES OF HISTORY EDUCATION FOR HIGH SCHOOL XI GRADERS)
}

\author{
Stanislaus Aris Wahyuwitomo $\square$; Universitas PGRI Madiun \\ Satrijo Budiwibowo; Universitas PGRI Madiun \\ Moh. Rifa'I; Universitas PGRI Madiun
}

\begin{abstract}
IT advances has been penetrating all of life including education. Educators need to help students exposed to cultural values to enable them filter things bad along with the IT invasion. Historical sites along with cultural values could be beneficial for such educational purposes. This research aims at investigating the historical site Umpak Reshogati located in Sogaten, Manguharjo District, Madiun City as well as the surrounding cultural values as potentials for educational sources of history education. This study involved such informants as the caretaker of the site, local citizens, local leaders, and government officials. Observation was carried out for 6 months beginning September 2019. Findings indicate that the historical site Umpak Reshogati was once the hall of Purabaya Regency, local people holds in high esteem such cultural values as gotong-royong (solidarity), faithfulness, and tolerance which are potentials for resources of history education.
\end{abstract}

Keywords: site Umpak Reshogati, Cultural Values, Educational Rsources, History Education.

\begin{abstract}
Abstrak: Kemajuan di bidang tehnologi dan informasi telah masuk kesemua lini termasuk di dunia pendidikan. Sebagai pendidik, dituntut membentengi anak-anak dari budaya luar melalui proses pembelajaran sejarah. Dalam mengajar sejarah, perlu memanfaatkan sumber pembelajaran sejarah lewat nilai-nilai budaya masyarakat sekitarnya. Di kelurahan Sogaten kota Madiun terdapat Situs Umpak Reshogati yang menarik untuk di kaji terutama tentang nilai-nilai budaya yang berpontesi sebagai sumber pembelajaran sejarah di SMA. Penelitian ini bertujuan untuk menganalisa aspekaspek nilai budaya masyarakat serta potensi sebagai sumber pembelajaran sejarah. Penelitian ini menggunakan pendekatan kualitatif, yaitu dalam menyajikan, memverifikasi serta menyimpulkan data lebih menekankan pada kajian interpretatif. Lokasi penelitian di kelurahan Sogaten kecamatan Manguharjo Kota Madiun, dengan waktu penelitian selama 6 bulan di mulai bulan September 2019 Februari 2020. Wawancara dilakukan lewat informan kunci yaitu: Juru kunci, masyarakat, pejabat desa, tokoh masyarakat. Observasi, dilakukan pada obyek penelitian dengan bantuan tape recorder, handycam, alat pencatat, dan lain-lainnya. Hasilnya, Situs Umpak Reshogati adalah bekas pendopo Kabupaten Purabaya dan masyarakat di sekitar situs mempunyai nilai-nilai budaya seperti gotongroyong, kesetiaan, ketaatan beragama, dan nilai toleransi yang berpotensi sebagai sumber pembelajar sejarah.
\end{abstract}

Kata kunci: Situs Umpak Reshogati, Nilai Budaya, Sumber Pembelajaran Sejarah

$\triangle$ aries.wahyuwitomo@gmail.com 
Citation: Wahyuwitomo, S. A., Budiwibowo, S. \& Rifa'i, M. (2020). The historical site umpak reshogati in Sogaten (A study of cultural values and their potentials for resources of history education for high school XI graders). Social Sciences, Humanities and Education Journal (SHE Jour nal), 1(2), 74 - 84. DOI: $10.25273 /$ she.v1i2.6717

\section{(c) BY-NC-SA}

Published by Universitas PGRI Madiun. This work is licensed under the Creative Commons Attribution ShareAlike 4.0 International License.

-NonCommercial- 


\section{PEDAHULUAN}

Kemajuan di bidang teknologi dan informasi saat ini hampir sulit dibendung. Seluruh dimensi kehidupan manusia sudah dimasuki dan dipengaruhi teknologi dan informasi, termasuk juga dalam dunia pendidikan. Di satu sisi, kemajuan teknologi dan informasi mendatangkan keuntungan atau nilai yang positif dan konstruktif. Akan tetapi di sisi lain, mendatangkan implikasi negatif dan destruktif (merusak).

Dampak destruktif kemajuan teknologi dan informasi yang kita rasakan saat ini adalah adanya fenomena intoleransi yang marak di berbagai daerah di negeri tercinta Indonesia dan sudah mulai mengkhawatirkan. Semangat primordialisme mulai mengarah kepada isu makar dan merongrong dasar Negara Pancasila yang sudah disepakati bersama oleh para pendiri bangsa tujuh puluh empat tahun yang lalu.

Anak-anak terancam oleh bahaya menyebaran paham-paham radikal yang begitu cepat yang berasal dari berbagai media. Dunia pendidikan diperhadapkan dengan perang budaya (rekayasa gagasan, penguasaan pikiran dan hati). Sebagai pendidik, guru dituntut untuk bertempur menanamkan nilai-nilai luhur budaya bangsanya serta terus menjunjung gagasan nasionalisme dalam diri peserta didik. Guru harus inovatif dan harus lebih cepat dari kaum ekstrimis yang ikut memanfaatkan kemajuan teknologi dalam menguasai pikiran peserta didik. Oleh karena itu guru menjadi tulang punggung bangsa dalam menangkis virus-virus yang merusak pikiran peserta didik.

Tantangan inilah yang menjadi pekerjaan rumah besar dunia pendidikan kita, yaitu bagaimana membentengi anakanak kita dari derasnya arus budaya luar serta bagaimana menanamkan nilai-nilai budaya bangsa sendiri melalui proses pembelajaran. Pembelajaran adalah proses interaksi siswa dengan pendidik dan sumber belajar pada suatu lingkungan belajar. Suatu aktifitas dapat dikatakan pembelajaran apabila di dalamnya terdapat interaksi antara guru, siswa dan sumber belajar (UU RI No. 20 Tahun 2003 Pasal 1 Ayat 20). Interaksi antara guru, siswa dan sumber belajar merupakan suatu proses yang bersifat permanen dan memiliki arah menuju pencapaian dari tujuan pendidikan nasional.

Dunia pendidikan di negara kita saat ini sedang mempersiapkan menuju generasi emas di tahun 2045, maka penanaman nilai-nilai budaya bangsa lewat pembelajaran sejarah menjadi sangat penting, terlebih dalam kurikulum 2013 (K13) mata pelajaran sejarah mendapatkan porsi jam yang banyak dibandingkan dengan KTSP 2006, bahkan mata pelajaran sejarah yang biasanya hanya di SMA, sekarang juga hadir di tingkat satuan pendidikan di SMK.

Tetapi menjadi ironis bila guru sejarah tidak mau berubah atau tidak mau keluar dari zona nyaman. Mungkin karena faktor usia, lingkungan sekolah, manajemen kepala sekolah, kurangnya ketersedian buku ajar, kondisi peserta didik dan banyak faktor-faktor lain yang memengaruhi kinerja guru sejarah. Kurikulum berubah, tapi guru tidak mau keluar dari zona nyaman, kegiatan belajar mengajar yang berjalan monoton dengan metode ceramah, mencatat dan menjawab soal dari buku teks. Ketersedian buku ajar juga menentukan keberhasilan mengajar sejarah, kadang guru hanya menggunakan buku yang menjadi pegangan wajib guru dan peserta didik. Mata pelajaran sejarah hanya 
menjadi pelajaran hafal menghafal belaka. Peserta didik kita dijejali dengan banyaknya data dan fakta sejarah yang hanya berisi tanggal, tahun, tempat, tokoh dan jalannya peristiwa. Dengan proses pembelajaran yang demikian maka menjadi sulit dalam merangsang emosi siswa untuk mencontoh karakterkarakter pelaku sejarah serta menanamkan nilai-nilai luhur bangsa nya sendiri.

Dalam mengajar sejarah, selain memberikan pengetahuan kesejarahan (kognitif) juga memperkenalkan nilainilai masyarakat, pengalamanpengalaman hidup manusia pada masa lampau (afektif). Untuk menunjang keberhasilan diperlukan sumber pembelajaran sejarah dengan memanfaatkan benda-benda bersejarah atau nilai-nilai budaya masyarakat yang ada di lingkungan sekitar siswa. Hal ini merupakan salah satu upaya untuk meningkatkan minat siswa terhadap pelajaran sejarah dengan menciptakan pola pembelajaran sejarah yang terkait dengan situasi di lingkungannya. Sedangkan untuk meningkatkan kemampuan dan pemahaman siswa akan materi, guru bisa memanfaatkan media pembelajaran seperti buku ajar,videovideo pendukung tentang situs atau tinggalan purbakala yang ada di sekitar siswa.

Di kelurahan Sogaten kecamatan Mangunharjo kota Madiun terdapat Situs Umpak Reshogati yang diyakin sebagai cikal bakal Kabupaten Madiun sekaligus tempat penyebaran agama Islam di wilayah Madiun. Situs ini merupakan peninggalan sejarah di masa akhir kerajaan Majapahit Hindu, dan munculnya Islam. (Pemerintah Kabupaten Daerah Tingkat II Madiun,1980: 15).
Pertanyaannya, Bagaimana sejarah Umpak Reshogati, dimana saja lokasinya dan apa fungsinya? Nilai-nilai budaya apa yang terdapat dalam masyarakat, terutama masyarakat di sekitar Situs Umpak Reshogati? Dan Faktor-faktor apa saja yang menjadi pendukung dan penghambat sebagai sumber pembelajaran sejarah di SMA kelas XI?

\section{METODE PENELITIAN}

Penelitian ini menggunakan pendekatan kualitatif (qualitative research), yaitu pendekatan yang dalam menyajikan, memverifikasi serta menyimpulkan data lebih menekankan pada kajian interpretatif. Penelitian kualitatif adalah proses penelitian yang bertujuan untuk memahami masalah sosial atau manusia, dengan membuat gambaran kompleks yang bersifat holistic. Menganalisis katakata, melaporkan pandangan-pandangan dari para informan secara rinci dan melakukan penelitian dalam keadaan alamiah, yang menurut Nasution (1996:18) di sebutnya sebagai penelitian naturalistik. Penelitian ini bertujuan untuk memahami dan menyelidiki tinggalan sejarah dan nilai budaya masyarakat berdasarkan tradisi metodologi penelitian tertentu. Untuk tujuan itu, peneliti menganalisis katakata, melaporkan perilaku-perilaku sosial dan nilai-nilai budaya warga masyarakat sekitar Situs Umpak Reshogati di Kelurahan Sogaten Kecamatan Mangunharjo kota Madiun dari para informan secara rinci, dan melakukan penelitian dalam situasi alamiah.

Lokasi penelitian ini dilaksanakan di kelurahan Sogaten Kecamatan Manguharjo Kota Madiun, dengan alasan di lokasi tersebut terdapat Situs Umpak Reshogati dan masyarakat sekitar situs 
tersebut mempunyai tradisi yang berbeda dibanding masyarakat Sogaten yang sebelah selatan, dan sangat kuat di pengaruhi oleh Kyai Reshogati baik keyakinan maupun nilai nilai ajaran leluhur masyarakat Sogaten. Penelitian dilaksanakan selama enam bulan yaitu mulai bulan september 2019 sampai dengan bulan Februari 2020.
Sumber data primer di dapatkan dari wawancara, sesuai dengan Arikunto (2006: 132) wawancara merupakan sebuah dialog yang dilakukan pewawancara untuk memperoleh informasi dari terwawancara. Informan kunci di pilih terkait dengan pengetahuan dari lamanya tinggal .

Tabel 1 Profil informan

\begin{tabular}{llcl}
\hline Sumber & Jenis Kelamin & Usia & Jabatan \\
\hline Informan 1 & Perempuan & 50 tahun & Sekretaris Desa \\
Informan 2 & Laki-laki & 45 ahun & Swasta \\
Informan 3 & Laki-laki & 68 tahun & Juru Kunci Makam \\
Informan 4 & Perempuan & 66 tahun & Ibu Rumah Tangga \\
Informan 5 & Laki-laki & 66 tahun & Tani /Srabutan \\
Informan 6 & Laki-laki & 62 tahun & Pensiunan ABRI \\
\hline
\end{tabular}

Data skunder,berupa dokumen sejarah dan profil objek, dengan melakukan observasi secara sistematik terhadap gejala yang tampak pada obyek penelitian. Sebagaimana disampaikan Arikunto (2006: 128), bahwa observasi adalah suatu kegiatan pemusatan perhatian terhadap suatu obyek dengan menggunakan seluruh alat indera. Pedoman observasi berkisar pada : Wilayah Situs Umpak Resogati, bendabenda yang bernilai historis, nilai-nilai yang terkandung dalam tradisi Bersih Desa, interaksi antar tetangga, serta perilaku yang tampak dalam masyarakat. Instrumen penelitian menggunakan logika dan berpikir analitik peneliti dibantu dengan alat-alat seperti tape recorder, handycam, alat pencatat, dan lain-lainnya. Keberhasilan pengumpulan data ini tergantung pada instrumen penelitian yang digunakan. (Moleong, 2001:167).

Sedangkan keabsahan data, menggunakan teknik pemeriksaan.
Menurut Lincoln (dalam Faisal,1990), teknik pemeriksaan didasarkan pada empat derajat kriteria pemeriksaan sesuai dengan yang disampaikan Lincoln (dalamFaisal,1990) yaitu kepercayaan, keteralihan, kebergantungan, dan kepastian. Sedangkan Tehnik analisis data yang di gunakan menggunakan cara menurut Patton (dalam Moleong, 2002) yaitu merupakan proses mengatur aturan data, mengorganisasikannya ke dalam suatu pola, kategori, dan satu uraian dasar.

\section{KAJIAN TEORI}

Situs Umpak Reshogati di kelutrahan Sogaten Kota Madiun ini merupakan peninggalan sejarah di masa akhir kerajaan Majapahit Hindu, dan munculnya Islam. (Pemerintah Kabupaten Daerah Tingkat II Madiun,1980: 15). Tentunya sejarah keberadaan Situs tidak bisa dilepaskan dari awal sejarah penyebaran Islam di Madiun. 
Pada masa Majapahit, daerah Pororogo, merupakan daerah yang lebih penting yang di kenal sebagai kerajaan Wengker. Pada tahun 1478 kerajaan Majapahit berakhir. kerajaan sebagai bagian dari Majapahit secara defacto menjadi kekuasaan Sultan Demak (Slamet Mulyana, 2005:29). Saat itulah awal misi penyebaran Islam di bumi pedalaman Jawa Timur bagian selatan (kerajaan Wengker) di jalanakan. Dalam Babad Ponorogo penyebaran islam di wilayah Wengker diwarnai perselisihan, perang yang menyakitkan, dan agak berbeda dengan proses penyebaran agama Islam di daerah pantai yang berjalan dengan damai dan diterima secara terbuka. (Ong Hok Ham, 2019:16).

Madiun tidak tercatat dalam babadbadab sebelumnya, daerah ini masih berupa hutan yang disebut desa Wonorejo. (Ong Hok Ham, 2019: 22). Menurut Serat Kanda, (dalam Slamet Mulyana, 2005:118), mencatat bahwa pada akhir abad XV, Raden Patah melakukan strategi baru penyebaran agama Islam dengan cara damai, yaitu mengawinkan putera mahkotanya yaitu Pangeran Surya Pati Yunus dengan Retno Lembah putri Raden Gugur yang masih keturunan terakhir Majapahit yang masih bercorak Hindu-Budha, di daerah Urawan (Delopo).

Pangeran Pati Yunus memindahkan ke utara menuju daerah yang kemudian dinamakan Purabaya (sekarang desa Sogaten). Beliau membangun pemukiman baru Islam, membuka lahan pertanian sesuai untuk memperkuat sektor Agraris dan memimpikan sebagai pusat agama Islam di Asia Tenggara menggantikan kemasyuran Majapahit. (Pemerintah Kabupaten Daerah Tingkat II Madiun, 1980: 98).
Pada tahun 1518 Pangeran Surya Pati Yunus menjadi Sultan Demak, Kyai Reksogati di utus sebagai pengawas wilayah Purabaya atas nama Demak, serta melanjutkan misi menyebarkan agama Islam di daerah tersebut. Langkah ini sangat tepat karena perkembangan Islam di wilayah Purabaya masih muda dan diperlukan pembinaan yang intensif agar pemeluk-pemeluk Islam yang baru, tidak berpaling kembali ke ajaran lama (Hindu). (Pemerintah Kabupaten Daerah Tingkat II Madiun, 1980: 97).

Lima puluh tahun lamanya Kyi Reshogati memimpin Purabaya berjalan damai dan harmoni, ajaran Islam di perkenalkan dengan lembut dan menjunjung nilai-nilai toleransi, sehingga mengesankan bagi penduduk lama yang ada di daerah Purabaya. Dalam buku Sejarah Kabupaten Madiun, (1980:96), ajaran Islam yang di ajarkan di daerah Purabaya didominasi ajaran Sunan Kalijaga yang telah menyebar sampai lereng Gunung Wilis.

Purabaya terus berkembang seiring dengan berjalannya waktu, meliputi bidang pemerintahan, sosial, budaya, ekonomi dan agama. Perkembangan ini di ikuti dengan tumbuhnya pemukiman baru, desa-desa baru bermunculan beserta Langgar, Surau, Mesjid sebagai tempat berdakwah dalam rangka proses islamisasi. (Pemerintah Kabupaten Daerah Tingkat II Madiun, 1980: 96).

Tahun 1521 Sultan Pati Yunus meninggal digantikan adiknya Sultan Trenggana. Selepas Trenggana wafat pada tahun 1546, Demak.terjadi perang saudara dengan kemenangan Joko Tinggkir menjadi Sultan Pajang. Bersamaan dengan dilantiknya Sultan Pajang, Sunan Kudus, diresmikan pula Pangeran Timur adik ipar Sultan menjadi Bupati di Purabaya. kemudian pada tahun 
1575, pemerintahan Purabaya pindah ke Kuncen. (Sejarah Kabupaten Madiun 1980: 102-104). Bekas Kabupaten Purabaya sampai sekarang masih bisa di jumpai di kelurahan Sogaten Kota Madiun.

Nilai-nilai budaya dalam sebuah masyarakat sangat dipengaruhi oleh keyakinan atau nilai-nilai, serta perilaku yang dianut oleh masyarakat setempat. Menurut Uhi ( dalam Hanif 2017:76-77), nilai budaya merupakan kesepakatan bersama yang terorganisir dan dapat mempengaruhi perilaku manusia, yang ber hubungan dengan lingkungan alam dan sosial, serta Sang Maha Pencipta.

Dalam mengajar sejarah, selain memberikan pengetahuan kesejarahan (kognitif) juga memperkenalkan nilainilai masyarakat, pengalamanpengalaman hidup manusia pada masa lampau (afektif). (Sartono Kartodirdjo,
2014:29). Menurut Atno (2010:93), dalam pembelajaran sejarah, di dalamnya dapat terintegrasi dengan materi lain seperti sumber sejarah yang ada di lingkungan sekitar. Siswa dilatih untuk menjalin komunikasi dan berdiskusi dengan teman, orang lain atau masyarakat sekitar sedangkan guru lebih berperan sebagai fasilitator.

Materi Pelajaran Sejarah hendaknya disesuaikan dengan kurikulum, guna menunjang tercapainya tujuan umum pendidikan nasional Indonesia. Oleh karena itu materi pelajaran diprioritaskan pada historiografi nasional yaitu melukiskan sejarah yang benar-benar bersifat Indonesia sentris. Menurut Adi Purnomo, 1997 (dalam Wartoyo, 2007: 58) guru harus pandai memilih batas-batas materi pelajaran seperti yang telah ditetapkan dalam KTSP.

Tabel 2.1 Materi Pelajaran Sejarah Kelas XI Semester I

\begin{tabular}{ll}
\hline Standart Kompetensi & Kompetensi Dasar \\
\hline Menganalisis Perjalanan & Menganalisis Pengaruh Perkembangan Agama \\
Bangsa Indonesia pada & dan Kebudayaan Hindu-Buddha terhadap \\
Masa Negara-negara & Masyarakat di Berbagai Daerah di Indonesia. \\
Tradisional. & Menganalisis Perkembangan Kehidupan Negara- \\
& negara Kerajaan Hindu-Buddha di Indonesia. \\
: & Menganalisis Pengaruh Perkembangan Agama \\
& dan Kebudayaan Islam terhadap Masyarakat di \\
& Berbagai Daerah di Indonesia. \\
: & Menganalisis Proses Interaksi antara Tradisi \\
Lokal, Hindu-Buddha, dan Islam di Indonesia \\
\hline
\end{tabular}

\section{HASIL PENELITIAN}

\section{Situs Umpak Reshogati}

Umpak-umpak yang berada di Situs terbuat dari batu andesit dan mayoritas berukuran besar, berbentuk persegi dan ada pula yang heksagon. Melihat ukuran umpak terlihat ukurannya besar-besar ini di sinyalir bukan berasal dari daerah setempat, karena jenis batu yang ada di sekitar sungai di sebelah situs, batubatunya berukuran kecil, paling besar seukuran kepalan tangan orang dewasa. Berarti umpak-umpak tersebut di bawa dari tempat lain yang berada dari hulu sungai.

Umpak-umpak adalah bekas alas atau pondasi tiang sebuah bangunan yang biasanya dari terbuat dari batu. Kondisi 
umpak beberapa sudah ada yang sudah rumpil dan pecah. Letak umpak-umpak, berada di dalam dan luar pemakaman. Umpak yang berada di luar pemakaman berada sekitar perempatan jalan menuju ke makam, totalnya berjumlah 7 buah, dengan perincian 1 buah di depan pemakaman umum jln. Srikaton, 3 buah di depan Mushola/Masjid Reshogati, 2 buah di jalan sekartejo, 1 buah berada dihalaman rumah Bpk. Sulisetyono. Sedangkan umpak yang berada di dalam komplek pemakaman umum berjumlah 14 buah, tersebar di samping pelataran area untuk acara bersih desa. Umpakumpak yang berada di dalam pemakaman berada satu titik dengan umpak-umpak yang berada di sekitar perempatan jalan. Jumlah total umpak sebanyak 21 buah.

Sejarah keberadaan Umpak-umpak di tempat ini tidak bisa di lepaskan dengan sejarah penyebaran agama Islam di Madiun dimulai pada akhir abad XV. Di mulai dengan perintah Raden Patah penyebaran agama Islam di pedalaman Jawa Timur dengan mengawinkan putera mahkotanya, Pangeran Surya Pati Yunus dengan Retno Lembah putri Raden Gugur. Pangeran Adipati Gugur adalah salah satu keturunan terakhir Majapahit yang masih beragama Hindu-Budha, yang tinggal sebelah utara Ponorogo yang disebut daerah Urawan (Delopo). Serat Kanda,(dalam Slamet Mulyana 2005: 118). Pangeran Pati Yunus memindahkan pemerintahanya ke utara melewati kali Madiun menuju daerah yang kemudian dinamakan Purabaya (sekarang desa Sogaten). Pada tahun 1518, Pangeran Surya Pati Yunus naik Tahta dan pemerintahan Purabaya di gantikan Kyai Reksogati guna melanjutkan misi menyebarkan Agama Islam di wilayah Purabaya, (Sejarah Kabupaten Madiun, 1989:97-98).
Dari hasil analisa tentang sejarah Situs Umpak Reshogati, di temukan bahwa di desa Sogaten Madiun adalah tempat Kabupaten Purabaya masa pemerintahan Kyai Reshogati, terdapat tinggalan benda purbakala berupa umpak-umpak, bekas pendopo Kabupaten Purabaya yang merupakan cikal bakal Kabupaten Madiun, yang letaknya tidak jauh dari sungai Madiun dan juga terdapat pemukiman penduduk lama.

Dari temuan diatas kemudian dilakukan pendalaman tentang lokasi, bentuk dan fungsi umpak, untuk memastikan posisi Pendopo Kabutapen Purabaya tersebut pada awalnya. Dari hasil analisa di temukan, umpak-umpak yang berada di dalam komplek Makam Reshogati didominasi umpak Heksagonal dengan ukuran yang besar untuk menyangga pilar Pendopo, maka letak Kabupaten Purabaya berada pada lokasi pelataran yang sekarang di gunakan upacara bersih Desa. Sedangkan umpak yang berada di luar Makam didominasi umpak persegi adalah bekas pondasi pagar Kabupaten. Bila di lihat dari lingkungan sekitar situs, posisi bekas Pendopo Purabaya posisinya lebih tinggi dari tanah sekitarnya, seperti sebuah tempat yang tanahnya ditinggikan dari sekitarnya. Sehingga umpak-umpak persegi berfungsi sebagai pondasi pagar serta untuk menghindari banjir.

Nilai Budaya Masyarakat Sekitar Situs. Pembahasan tentang nilai budaya masyarakat Sogaten bagian utara, peneliti berusaha mencari alur dari temuantemuan di lapangan tentang keyakinan atau kepercayaan masyarakat, apa yang dilakukan, siapa yang berpartisipasi dan faktor-faktor yang mempengaruhi aktivitas budaya tersebut. 
Budaya yang unik yang terdapat pada masyarakat Sogaten adalah "Bersih Desa'. Tradisi Bersih Desa ini merupakan salah satu upacara yang biasa dilakukan masyarakat Jawa yang merupakan ritual tahunan yang dilaksanakan di makam leluhur desa. Upacara dilakukan untuk mengungkapkan rasa syukur karena tanaman padi telah berhasil dipanen dan telah menghasilkan panenan yang memuaskan. Disamping itu, dilakukan penghormatan terhadap para leluhur yang telah meninggal dunia dan mendo'akan agar dosa-dosanya diampuni oleh Tuhan, serta agar yang ditinggalkan selalu mendapatkan keselamatan, murah rejeki dan mudah dalam mencari sandang pangan. Didalam upacara bersih desa biasanya masyarakat menggelar keseniaan Tayub, dan tari Gambyong.

Dari hasil analisa kami, tentang pelaksanaan upacara Bersih Desa, ditemukan bahwa: Masyarakat Sogaten meyakini bahwa bekas Pendopo Kabupaten tersebut adalah tempat Kyai Reshogati, dan mereka terus mengenang beliau dengan melaksanakan upacara Bersih Desa pada hari Jumat legi bulan Soro, dengan tetap melestarikan kesenian uyon-uyon serta tayuban.

Tentang nilai-nilai budaya masyarakat Sogaten dari pelaksanaan Upacara Bersih Desa adalah dijumpainya perilaku masyarakat yang konsisten yaitu hasrat untuk ikut bergotong royong, bersihbersih Punden, membuat terop menghias janur untuk acara bersih desa secara spontan. Dan kegiatan ini melibatkan masyarakat disekitar situs saja atau warga Sogaten bagian utara.

Selain itu kami juga menemukan bahwa dari seluruh masyarakat Sogaten bagian utara membuat buceng-buceng untuk di bawa ke Punden. Mereka melakukan dengan suka rela tidak ada paksaan sesuai dengan kemampuan masing-masing. Yang kaya bisanya membuat ayam panggang dalam bucennya, yang kurang mampu dengan lauk telor, tempe tahu, tidak ada masalah dan mereka melaksanakan dengan iklas. Mereka terlihat guyub rukun dan terus membawa nilai-nilai kesetiaan.

Dari analisa kami berikutnya, juga terdapat nilai-nilai Religius dalam seluruh rangkai upacara Bersih Desa. Mereka menjalankan Yasinan, Tahlilan, pada malam Tirakatan menjelang Bersih Desa. Besoknya juga ada acara memberikan santunan kepada anak-anak yatim serta Doa Bersama (Selamatan) untuk bucengbuceng yang natinya akan dibagikan kepada seluruh masyarakat untuk dimakan dirumah masing-masing. Ini adalah bentuk nilai-nilai relegius yang telah menjadi perilaku hidup dalam masyarakat Sogaten dalam setiap kegiatan Bersih Desa.

Selain budaya Bersih Desa, masyarakat sekitar situs juga memiliki perlaku sosial dalam kehidupan bertetangga seperti rasa saling menghargai walau berbeda keyakinan. Salah satu contoh konkrit, yang ditemukan pada saat ada salah satu keluarga beragama katolik meninggal, masyarakat sogaten datang berkumpul melayat membawa sumbangan, seperti layak umumnya warga lainnya yang meninggal. Ada acara ibadat kematian, masyarakat menghormatinya, hingga acara bisa berlangsung lancar dan hikmat. Selain itu masyarakat Sogaten bagian utara juga tidak keberatan dengan adanya Gereja di lingkungannya, tidak pernah ada laporan gesekan masalah agama. Ini adalah bentuk nilai-nilai budaya tolerasi masyarakat Sogaten bagian utara yang masih lestari sampai saat ini. 


\section{Faktor Pendukung dan Penghambat sebagai Sumber Pembelajaran Sejarah}

Fokus pembahasan ini mencoba menganilisa kesesuaiannya dengan Materi Pelajaran Sejarah Kelas XI pada Semester I dengan Standart Kompetensi : Menganalisa Perjalanan Bangsa Indonesia pada masa negara tradisional, dan Kompetensi Dasar point 1.7 Menganalisis Pengaruh Perkembangan Agama dan Kebudayaan Islam terhadap Masyarakat di Berbagai Daerah di Indonesia.

a) Faktor Pendukung

Faktor pendukung (1) Situs Umpak Reshogati merupakan situs Islam, di masa awal perkembangan Islam di Madiun. Fakta sejarah dengan ditemukannya benda purbakala berbentuk umpak-umpak bekas tiang pendopo Kabupaten Purabaya. Faktor pendukung (2) nilai-nilai Relegius yang mewarnai terdapat kehidupan masyarakat Sogaten, seperti melksanakan Yasinan, Tahlilan, dan Doa bersama (selamatan) Faktor pendukung (3) nilai-nilai Kesetiaan seperrti mengirim makanan ke Punden yang berisi nasi, lauk, sayur secara iklas untuk di doakan di Punden. Faktor pendukung (4) yaitu nilai-nilai toleransi yang ada dalam masyarakat sogaten seperti ajaran Kyai Resogati tentang lelaku yang baik. Dan sampai sekarang tidak ada pertengkaran prekara agama. Selain itu juga di sogaten juga ada gereja dan tidak menjadi kendala pada masyarakat sekitarnya.

b. Faktor Penghambat .

Faktor penghambat (1) letak atau posisi umpak-umpak, sekarang sudah banyak berubah, tidak sesuai dengan tempat aslinya, adanya pergeseran letak batu-batu sehingga sulit untuk menganailsa bentuk dan besaran Pendopo. Faktor penghambat kebiasaan minum arak pada acara Tayuban, sehingga menjadi penghalang mengajarkan budaya yang positif ke perserta didik. Faktor penghambat .

\section{KESIMPULAN}

Saat ini kemajuan di bidang teknologi dan informasi sudah masuk keseluruh dimensi kehidupan manusia termasuk juga dalam dunia pendidikan. Tantangan kita adalah, bagaimana membentengi anak-anak kita dari budaya luar dengan menanamkan nilai-nilai budaya bangsa sendiri melalui proses pembelajaran sejarah.

Dalam mengajar sejarah, selain memberikan pengetahuan kesejarahan (kognitif) juga perlu memperkenalkan nilai-nilai masyarakat, pengalamanpengalaman hidup manusia pada masa lampau (afektif), sebagai sumber pembelajaran sejarah. Maka dengan demikian sumber pembelajaran sejarah dapat memanfaatkan apa yang ada di lingkungan sekitar siswa.

Sebuah peristiwa sejarah perkembangan Islam di Madiun di mulai dari Situs Umpak Reshogati dengan fakta fisik kebudayaan berupa umpak-umpak bekas pendopo Kabupaten Purabaya pada masa Kyai Reshogati yang letaknya di dalam makam Reshogati, karena di tempat tersebut banyak umpak-umpak heksagonal, sebagai penyangga pilar-pilar Pendopo. Sedangkan umpak persegi yang berada di luar makam, adalah bekas pondasi pagar Kabupaten.

Budaya yang unik pada masyarakat sekitar Situs Reshogati adalah secara turun temurun melaksanakan Bersih Desa, dengan keyakinan mengenang leluhur desanya yaitu Kyai Reshogati. Tradisi tersebut mengandung nilai-nilai budaya seperti: (1) Nilai Gotong-royong berupa perilaku kerja bakti pada acara Bersih Desa, (2) Nilai Kesetiaan, berupa 
perilaku mengirim buceng-buceng ke Punden (3) Nilai Religius, berupa perilaku syukur kepada Tuhan seperti budaya Yasinan, Tahlilan, Sodaqoh serta Slametan (doa bersama-sama). (4) Nilai Toleransi, yaitu berupa budaya saling menghormati dengan yang berbeda keyakinan.

Faktor-faktor pendukung sebagai sumber pembelajaran sejarah yaitu : (a) fakta sejarah, berupa bekas tiang pendopo Kabupaten Purabaya awal perkembangan agama Islam di Madiun, sejalan dengan materi pelajaran Sejarah kelas XI di semester I yang bisa dijadikan obyek belajar. (b) Nilai-nilai budaya yang terkandung dalam masyarakat Sogaten seperti nilai Gotong Royong, Religius, Kesetiaan dan Nilai-nilai toleransi bisa dijadikan contoh yang nyata dalam menanamkan nilai budaya luhur bangsanya.

Adapun faktor-faktor penghambat sebagai sumber pembelajaran sejarah yaitu : (a) Posisi umpak-umpak, sekarang sudah banyak berubah, adanya pergeseran sehingga sulit membayangkan bentuk dan denah bangunan pendopo Kabupaten Purabaya.(b) Ada tradisi minum arak pada pelaksanaan Bersih Desa terutama saat acara Tayuban, sehingga menjadi penghalang dalam mengajarkan budaya positif ke perserta didik.

\section{DAFTAR PUSTAKA}

Nasution, ( 1996), Metode Penelitian Kualitatif Naturalistik, Jakarta : Sinar Grafika

Lincoln, Yvonna S \& Egon G. Guba. 1985. Naturalistic Inquiry. California: Sage

Arikunto, S. 2006. Metode Penelitian Kualitatif. Jakarta: Bumi Aksara
Moleong, Lexy J. (2001).Metodologi Penelitian Kualitatif.Bandung: Remaja Rosdakarya

Faisal, Sanapiah. 1990. Penelitian Kualitatif (dasar-dasar dan aplikasi). Malang: Ya3 Malang

Pemerintah Kabupaten Daerah Tingkat II Madiun, 1980, Sejarah Kabupaten Madiun

Prof. Slamet Mulyana, 2005, Runtuhnya Kerajaan Hindu-Jawa dan Timbulnya Negara-Negara Islam di Nusantara, penerbit LkiS Yogjakarta.

Ong Hok Ham (2018), Madiun Dalam Kemelut Sejarah. Penerbit PT Gramedia Jakarta

Dr. Purwadi 2007, Babad Majapahit. Penerbit Media Abadi. Yogjakarta

Dr. Purwadi 2003, Sejarah Sunan Kalijaga. Pernerbit PT Persada. Yogjakarta

Soedjipto Abimanyu 2014, Babad Tanah Jawi, Penerbit Laksana Jogjakarta

Muhammad Hanif, 2017 , Kesenian Dongkrek ( Studi Nilai Budaya dan Potensinya sebagai Sumber Pendidikan Karakter ) : Gulo Wentah: jurnal studi sosial 2(2)132-141

Wartoyo, 2007. Implementasi pendekatan kontekstual sebagai upaya peningkatan kualitas pembelajaran di Sekolah, Universitas Sebelas Maret, 2007.

Sartono Kartodirjo, (2014), Pengantar Sejarah Indonesia Baru 1600-1900 dan Pengantar Sejarah Indonesia: Sejarah Pergerakan Nasional (2014) 